\title{
Enlightenment of Japan's Low - carbon Economy Building on China
}

\author{
Jialin Guan ${ }^{1,}$,, $\mathrm{Ke} \mathrm{Li}^{2}$, b, Xinmeng Lv ${ }^{3, \mathrm{c}}$ \\ 1, 2, 3 Street3699, Changchun, Jilin province, China \\ Jilin University of Finance and Economics \\ amissguanjialin@aliyun.com, btiger_316@126.com, c996937917@qq.com
}

\begin{abstract}
Keywords: China, Low-carbon Economy,Advice.
Abstract: China puts forward the green development strategy in the "Twelve-Five Year" Plan. In the report of "The 18th National Congress of the Communist Party of China, "green" is the core of ecological civilization construction of five development concepts, "green" is the core of ecological civilization construction. The Third Plenary Session of the 18th National Congress of the Communist Party of China promotes the implementation of ecological civilization System Construction further. This shows that China is moving towards a low-carbon economy. In the aspect of promoting low-carbon economy, Japan, in many felids, has achieved remarkable successes. This paper, based on the current situation of China's low-carbon economy and taking lessons from the successful experience of low-carbon economy in Japan, points out the necessity of promoting low-carbon economy in China and puts forward the advices.
\end{abstract}

\section{Introduction}

In 2003, the term "low-carbon economy" was first proposed in the British energy white paper, "our future energy: the creation of a low-carbon economy." The core of the low-carbon economy is to improve efficiency of energy and to reduce carbon emissions. Since that, Japan points out clearly in "Fukuda Vision" that greenhouse gas emissions are decreased $60 \%$ to $80 \%$ by 2050 [1].The current rate of ecological overload is around $50 \%$ in the world, while China is close to $150 \%$ which becomes one of the most ecologically overloaded countries in the world [2]. China has to focus on low carbon development and ecological problems. Japan has made remarkable achievements in pushing the construction of low carbon society and gradually formed a set of complete implementations. The experience has important reference value for China to develop low-carbon economy under the background of green economy.

\section{The Experience of Building Low-Carbon Economy in Japan}

After World War II, Japan focus on repairing the country's economy with industrial recovery plan. Coal is a major source of energy for industrial development, and Japanese government has formulated policies to accelerate the development of the coal and steel industries. However, air and water and environmental pollution caused by long-term coal acquire have seriously jeopardized the safety of Japanese people. In the 1950s and 1970s, four major public hazards shocked the world because of long period problem of environmental pollution. From the late 1950s, Japanese government attached great importance to this and launched a series of measures to tackle the four major public hazards. In 1971, Japan established the environmental protection department to ensure the implementation of ecological environment.

According to Japan's energy and economic research, Japan's energy consumption grew at an average annual rate of 2.2 percent between 1960 and 1970, up from 10.1 percent a year earlier. By the first oil crisis of 1973, oil accounted for 77.9 percent of energy consumption [3]. Due to restricted in oil imports in Japan; Japanese government vigorously promotes energy conservation and technology of emissions reduction to cope with the energy crisis, which is the beginning of Japan`s low-carbon economics. 
Japan is Constantly Proposing New Initiatives and Strategies for Low-Carbon Development. In 1998, Japan promulgated Global Warming Countermeasures Promotion Act, and put forward the "new national energy strategy" and "global economic strategy" by generating former founding "environment" strategy in 2006. In 2008, Japan carried out the "plan of action to implement low carbon society", and put forward that greenhouse gas emissions in 2020 to 1990's target of 25\% less than in2009[4]. The government concentrates on traditional industrial upgrading and technological innovation at the same time as well as regards low carbon technology as a focal point of the future technological innovation In 2010, on the basis of new economic growth strategy, Japanese government put forward the strategy of "green growth", which emphasized on the development of energy saving, new energy, new materials, green economy and the health care industry to conquer the highest position in a new round of economic growth. Japan has also formed a good interactive management system among government agencies, energy units and civil society organizations.

Japan Implements Measures to Ensure Policies. Japan has formed a good interactive energy management system among government agencies, energy units and civil society organizations. The central government department in charge of energy saving and its dispatched institutions, individual bear policy deployment, goal planning, standards, and to accept the report and implement the inspection work. The civil society shall conduct consultations, services, examinations and appraisals according to the entrusted government. All kinds of energy-using units are required by the government to submit energy-saving reports regularly, actively develop or introduce energy-saving technologies, and carry out energy-saving activities for the public.

Japan Builds Low-Carbon Eco-industrial Zone. Since the 1960s, Japanese government had embarked on a low-carbon, eco-friendly industrial park. For nearly half a century, Japan has increased funding on domestic research and development. After more than 20 years of construction, industrial park has become a new city which is regarded the high technology industries as main body, combined scientific research, teaching, production, management and social services into new integration, and it involved more than 40 scientific research institutions and more than 200 high-tech enterprises, involved physics, electronic materials, agriculture, marine environment, meteorology, microbiology, and many other fields. Japan's industrial park development model has also changed from the high-tech park to the third generation of eco-industrial parks. [5]

Japan Actively Develops Renewable Energy Sources. Actively developing renewable energy is an important way to make up for the shortage of energy. In 2012, Japanese government began to use renewable energy system that power companies had its social obligations to buy solar energy, wind power, hydropower, geothermal, biomass power at a fixed price on a regular basis, which optimized and improved power generation infrastructure, adjusted the structure of productive energy and gradually increased the renewable energy share in total energy. The energy capacity of Japan's domestic renewable equipment increased by $32 \%$, and structure of power energy had been obviously improved by the end of 2014; Japan's renewable energy in electricity proportion has reached $10.7 \%$ [3].

Japan focuses on education of energy conservation and environmental protection. Whether in school or society, Japan is paying a lot of attention to low carbon energy education. The classification of garbage and how to handle also become the basis of the school's education. Much of the design detail in Japan's public service system can be seen as a guide to conservative and environmental protection. At the same time, Japanese companies set up "the construction of the sustainable development of society, the core values of environmental protection and energy saving for employees, consumers and the public, more importantly, it is also a measure of whether it is a competitive enterprise or not. 


\section{The Necessity to Promote China`s Low-Carbon Economy}

Energy Demands is Increased and Utilization is Low. According to the development experience of the developed countries, energy consumption is insuperable. China, in particular, is in a stage of industrial transformation with huge energy demand. Between 2000 and 2020, the state plans to increase GDP by four times, and energy consumption by a factor of 1, which means the energy elasticity should be 0.5 [6]. But in the past three years, the coefficient had been more than 1.3, which means energy demand has exceeded expectations. According to the relevant institutions study, per million dollar GDP energy consumption of China is $1274 \mathrm{t}$ of standard coal, 2.4 times higher than the world average, 2.5 times higher than the United States, the European Union and Japan respectively 4.9 times, 8.9 times. Coal is the backbone of China's energy for the next 30 years, although coal's share of total energy will decline from $75 \%$ to $60 \%$ [7]. The power generation, cement, steelmaking, electrolytic aluminum and other units' energy consumption of China are $20 \% \sim 30 \%$ higher than advanced technology. Under this energy-consuming circumstance, China's energy efficiency is extremely low. The energy efficiency is 10 percentages below the international advanced level, and the most serious is the middle part of the energy use such as processing, conversion and storage loss is large and the waste is serious. When summarizing the characteristics of China's energy use, one is the large energy consumption, second is the coal resources mainly, and third is that the energy efficiency is low and need technical innovation and low-carbon clean energy.

High Carbon Emissions and Serious Environmental Pollution. Coal mining and direct combustion have caused serious ecological and environmental pollution problems. Most of the pollutants in the air are $\mathrm{SO} 2, \mathrm{Hg}, \mathrm{CO} 2$, and $\mathrm{PM} 2.5$, which are 70 percent to 80 percent of the pollutants due to the direct combustion of coal. At present, the phenomenon of acid rain is seen in 30 to 40 percent area of China, and the respiratory diseases are increasing. It all harms human health. It is not only China, but the world is actively pursuing various measures to save energy and reduce emissions. This has also prompted China to develop new, low-carbon, reusable resources.

Lifestyle Changes Lead to Higher Carbon Emissions. Since the reform and opening up, the quality of life has improved significantly and the lifestyle has been colorful. First, in recent years, high-rise buildings have been built up, the area of housing has increased significantly, and the energy consumption of the unit construction area has been high. At present, China's construction area is about two to three times compared to developed countries. Second, there is a significant increase in the number of private cars, as well as increasing carbon emissions, which is one of the reasons why carbon emissions are so high.

\section{Suggestions for Developing Low-Carbon Economy in China}

First, we need to implement the strictest law and regulation the most rigorous legal system to provide reliable guarantee for the construction of ecological civilization. Improve the environmental protection laws and regulations, which is fatal to environment protection. Second, we will improve the evaluation system for social development. Build system of perfect ecological, low-carbon civilization, and the most important thing is that putting the resource consumption and environmental damage, ecological index of ecological civilization construction into the evaluation system. The Third Plenary Session of the 18th National Congress of the Communist Party of China put forward to implement energy and water consumption, restrict land and total intensity of double action the law enforcement system of environmental protection agencies that under the vertical management of provincial monitor. Third, establish accountability system. We will explore the development of natural environment balance sheets and conduct the audit of natural assets for leading officials. Fourth, innovation is the first force driving of development. We will explore new sources of energy, increase financial input and develop saving resources. Fifth, everyone should aware of the ecological red line and keep it in mind. At the same time, we advocate the low carbon social consciousness and behavior to build a low carbon society. Only by building a low-carbon life and advocating low carbon consumption patterns can we achieve a low carbon society. 


\section{Acknowledgements}

This work was financially supported by Jilin Provincial Social Science Fund (2015BS42), Social Science Research Fund of Jilin Provincial Education Department "The Twelfth Five-Year Plan" (2014 No.137)and Science Research Project of Jilin University of Finance and Economics (2016Z02).

\section{References}

[1] X.J. Meng: Low-carbon economy: The dilemma, mistakes and policies of china from abroad experience. Journal of BeiHua University (Social Sciences) Vol.1, 2010

[2] S.P. Peng, X.Z. Sun: The Main Challenges and Strategic Countermeasures of developing Green Economy in China. China Population, Resources and Environment, Vol.24.3, 2014

[3] J.B. Wang: The Choice of Low-carbon Paths for Japan's Industrial Upgrading under the Restriction of Resources and Environment - Taking the Development of Japan (Ecological) Industrial Park as an Example, Asia - Pacific economy Review, Term1,2014

[4] C.C. Tian, Q.M. Chai: Japan's Experience and Lessons in Building Low - Carbon Society, Asia Pacific economy Review, Term1, 2016

[5] A. Li, J.W. Chang: Experience and Enlightenment of Promoting the Construction of Green Low carbon Cities in Japan, China Economic Times, Fifth layout, 2016

[6] W.D. Ni: Energy Status and Strategic Countermeasure of Our Country, Shanxi Energy and Conservation, Term2, 2008

[7] Y. Li, H. Han: The Present Situation of Energy in China and the Thinking of Future Development, Inner Mongolia Science Technology \&Economy, Term 1, 2014 